\title{
A TRADUÇÃO INTERLINGUAL E INTERMODAL EM UM EXCERTO DE "MAUS", DE ART SPIEGELMAN
}

\section{THE INTERMODAL AND INTERLINGUAL TRANSLATION IN AN EXCERPT OF ART SPIEGELMAN'S "MAUS"}

\author{
Márcia Tavares Chico' \\ [https://orcid.org/0000-0001-7574-9655] \\ Roberta Rego Rodrigues ${ }^{2}$ \\ [https://orcid.org/0000-0002-1580-1789] \\ DOI: $10.30612 /$ raido.v15i37.12844
}

\begin{abstract}
RESUMO: Este artigo objetiva verificar como a representaçăo é construída no tocante à linguagem verbal e à linguagem visual em um excerto da graphic novel Maus, de Art Spiegelman e em duas de suas traduçóes para o português. Categorias da metafunçăo ideacional foram usadas para classificar os Participantes, os Processos e as Circunstâncias na relaçấo (1) do visual com o verbal nos três trechos; na relaçấo (2) do verbal das traduçóes em comparaçăo ao verbal do texto-fonte; e na relaçăo (3) do verbal das traduçôes entre si. Os resultados mostram que na relaçăo (1) há a realizaçâo recorrente de Atores e Dizentes; na relaçâo (2), sâo evidenciadas as dissimilitudes sistêmicas entre a língua inglesa e a língua portuguesa; e, por fim, na relaçăo (3), as traduçōes apresentam com frequência Processos Materiais e Relacionais com pequena variaçăo em seu número. Pode-se observar que, na relaçăo (1), quando se manifesta a traduçáo intermodal, há de fato a indissociabilidade entre o visual e o verbal. $\mathrm{Na}$ relaçâo (2), notam-se as idiossincrasias conforme as escolhas da tradutora, do tradutor e do autor com base nos sistemas linguísticos envolvidos. Na relaçáo (3), verificam-se algumas diferenças de representaçăo entre o português brasileiro e o europeu.
\end{abstract}

Palavras-chave: Estilística Tradutória; Linguística Sistêmico-Funcional; Gramática do Design Visual; Graphic Novel; Maus.

ABSTRACT: This paper aims to verify how representation is realized verbally and visually in an excerpt of the graphic novel Maus by Art Spiegelman and in two of its translations to Portuguese. Ideational metafunction categories were used to classify Participants, Processes, and Circumstances when it comes to the relation (1) between visual and verbal in the three excerpts; the relation (2) of the verbal modes in the

1 Doutoranda em História pela Universidade Federal de Pelotas. Mestrado em Letras (2017) pela mesma instituiçăo. Especialista em História em Quadrinhos (2020) pela Faculdades EST. Graduada em Letras Português/Inglês e Respectivas Literaturas (2013) pela Universidade Federal de Pelotas. Graduanda em Letras Traduçăo Inglês/Português. Bolsista PROBIC/FAPERGS (2018-2020). Contato: marciatch@gmail. com

2 Doutora (2010) e Mestra (2005) em Linguística Aplicada pela Universidade Federal de Minas Gerais. Professora de Traduçăo da Universidade Federal de Pelotas. Contato: roberta.rego@ufpel.edu.br 
translations when they are compared to the source text; and the relation (3) of verbal modes in the translations per se. The results show that in the relation between visual and verbal the realization of Actors and Sayers is recurrent; for relation (2), systemic dissimilitudes between Portuguese and English are made evident; and for relation (3), the translations frequently show Material e Relational Processes with only a slight variation in numbers. It can be observed that regarding relation (1), when the intermodal translation is manifested, there is, indeed, the inseparability between visual and verbal. Regarding relation (2), idiosyncrasies related to choices made by the translators and the author are noticed between the linguistic systems involved. Regarding relation (3), some differences between Brazilian and European Portuguese can be verified.

Keywords: Translational Stylistics; Systemic Functional Linguistics; The Grammar of Visual Design; Graphic Novel; Maus.

\section{INTRODUÇÃO}

O presente artigo tem por objetivo analisar um excerto da graphic novel Maus (1991), escrita e desenhada por Alt Spiegelman, e duas de suas traduçóes, uma para o português brasileiro e outra para o português europeu, sob a luz da Estilística Tradutória, da Linguística Sistêmico-Funcional e da Gramática do Design Visual.

O enfoque do trabalho é a traduçăo interlingual, ou seja, aquela que ocorre entre línguas diferentes (JAKOBSON, 1959/2007), vista sob a ótica da Estilística Tradutória, termo cunhado por Malmkjaer $(2003,2004)$ para tratar da análise estilística de textos literários traduzidos. Utilizamos, também, a Linguística Sistêmico-Funcional, a qual analisa como o significado é construído em um texto (HALLIDAY; MATTHIESSEN, 2014). Além do conceito de traduçăo interlingual, utilizamos o conceito de traduçâo intermodal, aquela que se dá na mudança de um signo para outro (KRESS, 2003 apud DOLOUGHAN, 2011). Por último, a Gramática do Design Visual nos mostra como o modo semiótico năo-verbal é realizado de uma maneira particular, o qual pode ser diferente do modo semiótico linguístico (KRESS; van LEEUWEN, 2006).

Ao que parece, os modos semióticos verbal e visual năo săo com frequência concomitantemente investigados em graphic novels, quanto mais acompanhados de suas traduçōes. Desejamos com este artigo contribuir para preencher de certo modo essas lacunas ao adotarmos uma perspectiva funcionalista da linguagem pelo viés do componente experiencial da metafunçâo ideacional hallidayana.

As perguntas que guiam a pesquisa săo: como se realiza o modo semiótico visual nos excertos selecionados? De que maneira ele dialoga com o modo verbal? Como se realiza a traduçăo interlingual? E, por fim, o que pode ser dito ao compararmos as traduçóes do ponto de vista verbal?

Um trecho da graphic novel e seus trechos correspondentes nas traduçóes para o português serăo analisados a partir de sua representaçăo (metafunçáo ideacional). Procuraremos entender como a representaçâo se dá tanto na parte linguística quanto na parte visual e como os diferentes modos semióticos se aproximam e se diferenciam. $O$ trabalho justifica-se por apresentar um foco mais abrangente para os estudos de representaçấo no âmbito dos Estudos da Traduçâo, utilizando tanto a 
Linguística Sistêmico-Funcional quanto a Gramática do Design Visual e as aplicando às histórias em quadrinhos, campo ainda pouco explorado de pesquisa linguística e tradutória.

O artigo está dividido em diferentes seçôes. A primeira apresenta nosso referencial teórico, explicitando as teorias e os conceitos utilizados, tais como Estilística Tradutória, Linguística Sistêmico-Funcional, Traduçăo Intermodal e Gramática do Design Visual. A seguir, apresentamos nossa metodologia, na qual também explicamos, com mais detalhes, a obra que será analisada bem como suas traduçôes para português brasileiro e português europeu. Na metodologia, explicamos também os procedimentos de análise que propiciaram os resultados. A seçâo seguinte trata da análise das obras e, por último, apresentamos nossas consideraçōes finais com base nos resultados obtidos.

\section{REFERENCIAL TEÓRICO}

Jakobson (1959/2007) considera que existem três tipos de traduçăo: 1) a traduçăo intralingual ou reformulaçâo; 2) a traduçăo interlingual ou a traduçâo propriamente dita; e 3) a traduçâo intersemiótica ou transmutaçâo.

Segundo o autor, a traduçăo intralingual ocorre dentro de uma mesma língua, de uma palavra a outra mais ou menos sinônima ou a um circunlóquio. Entretanto, náo podemos afirmar que a sinonímia seja igual a uma equivalência completa (JAKOBSON, 1959/2007). Isso também acontece no que tange à traduçâo interlingual, a que ocorre entre línguas diferentes: năo há equivalência completa entre as unidades do código, "ao passo que as mensagens podem servir como interpretaçōes adequadas das unidades de código ou mensagens estrangeiras" (JAKOBSON, 1959/2007, p. 65).

Para Jakobson (1959/2007), em casos de traduçāo interlingual pode ser que mensagens de um idioma nâo sâo substituídas por unidades de código, mas sim por mensagens completas de outro idioma. E isso pode ser considerado uma forma de discurso indireto, em que a tradutora "recodifica e transmite uma mensagem recebida de outra fonte" (JAKOBSON, 1959/2007, p. 43). A traduçăo intersemiótica ou transmutaçâo é tratada de maneira breve por Jakobson (1959/2007). Segundo o autor, a traduçâo intersemiótica acontece quando os signos verbais sāo representados por intermédio de signos năo-verbais. Citamos Jakobson (1959/2007) pelo fato de o autor tratar dos três tipos de traduçăo, dentre as quais duas săo de interesse deste artigo, a saber, a traduçâo interlingual e a traduçâo intersemiótica (JAKOBSON, 1959/2007). A traduçăo intersemiótica dialoga com a traduçăo intermodal, como veremos adiante.

No âmbito da traduçâo interlingual, utilizamos Malmkjaer $(2003,2004)$ que, ao tentar compreender a estilística dos textos traduzidos, cunha o termo estilística tradutória. Segundo a autora, atribui-se à análise estilística uma "preocupaçāo com a semântica do texto"3 (MALMKJAER, 2003, p. 38), sendo que esta preocupaçăo é uma forma de distinçâo entre estilística e estilo. Malmkjaer (2003, 2004) aponta que estilo seria a regularidade com que certos elementos, itens e estruturas ocorrem em um texto.

3 No original: "concern with the semantics of text". 
Quando se trata de estilística tradutória, as escolhas de uma tradutora săo ainda mais circunscritas do que as de uma escritora: "as escolhas linguísticas de uma tradutora estăo limitadas ainda mais pelo que o texto original afirma"4 (MALMKJAER, 2003, p. 39). Segundo a autora, essa restriçăo năo é encontrada em análises estilísticas que năo sejam tradutórias. Assim, a estilística tradutória procura explicar o porquê de a traduçấo de um texto vir a ter o significado que tem, baseando-se, sempre, no textofonte (MALMKJAER, 2003).

Em textos traduzidos, a tradutora ocupa o espaço da autora e a tradutora pode possuir visōes específicas quanto ao texto a ser criado (BERMAN, 1995 apud MALMKJAER, 2004). Sendo assim, Malmkjaer (2004), entăo, comenta sobre as escolhas no momento de escrever e de traduzir. Uma escritora tem uma ampla liberdade quando escreve textos criativos, fato que pode năo ocorrer no ato de traduzir (MALMKJAER, 2004).

Conforme Malmkjaer (2004), a mediaçăo através da traduçâo envolve duas línguas, cujos detalhes náo corresponderáo. Dessa forma, a tradutora terá que fazer escolhas linguísticas e enfrentar restriçóes. Malmkjaer (2004) aponta que um texto mediado pela traduçăo possui quatro características específicas: 1) um texto mediado é afetado pelas escolhas e pela interpretaçăo da mediadora; 2) a mediaçăo através da traduçáo tem um propósito; 3) essa mediaçâo e as escolhas da mediadora podem criar um texto com um propósito diferente do apresentado pelo original; e 4) o público-alvo do texto mediado é diferente do público-alvo do texto-fonte.

Considerando que a estilística tradutória (MALMKJAER, 2003, 2004) investiga de modo linguístico os textos literários-fonte e seus textos literários-alvo correspondentes, selecionamos a Linguística Sistêmico-Funcional para empreender a análise proposta neste artigo.

Halliday e Matthiessen (2014) consideram a linguagem como sendo abrangente, manifestando primariamente os sistemas e funçōes. Levando isso em conta, a Linguística Sistêmico-Funcional analisa como os significados săo construídos, em um texto, e de que maneira o texto possui determinado significado para a leitora (HALLIDAY; MATTHIESSEN, 2014). Segundo os autores, a Linguística Sistêmico-Funcional é tida como uma série de sistemas, que esclarece como a usuária da língua pode realizar significados.

Săo postuladas, no âmbito da Linguística Sistêmico-Funcional, três metafunçōes que nos auxiliam a compreender a funcionalidade da linguagem, quais sejam, interpessoal, ideacional ou textual (HALLIDAY; MATTHIESSEN, 2014).

A metafunçăo interpessoal refere-se ao uso da língua para a comunicaçăo com o outro. Já a metafunçâo ideacional, foco deste artigo, refere-se ao uso da língua para falar sobre o mundo, enquanto a metafunçâo textual seria a organizaçáo da linguagem a um determinado contexto (THOMPSON, 2014).

Segundo Rodrigues (2014), as abordagens do discurso usadas nos Estudos da Traduçăo utilizam a Linguística Sistêmico-Funcional de Halliday, principalmente por causa que esta considera o significado como uma escolha, o que remete à traduçấo, pois esta é uma atividade que "demanda a seleçăo pragmática da língua durante o processo

4 No original: "a translator's linguistic choices are limited, further, by what the original text said." 
de traduçâo"s (RODRIGUES, 2014, p. 188). Para Halliday (2001 apud RODRIGUES, 2014), a traduçăo acurada das realizaçóes ideacionais é importante, pois se a realizaçáo das experiências dos mundos interno e externo năo for bem feita, o texto traduzido náo será "bem-sucedido" em termos de representaçăo.

Hatim e Mason (1997 apud MUNDAY, 2012 apud RODRIGUES, 2014) veem a transitividade e a modalidade como meio de entender os processos ideológicos da traduçâo. Os autores acreditam que diferentes interpretaçóes podem ser alcançadas por causa de mudanças na transitividade e que erros de interpretaçâo podem ser causados por mudanças na modalidade. Para os autores, a dinamicidade e a estabilidade, ao traduzir-se um texto, podem apresentar estratégias úteis para as tradutoras.

Para Baker (2011 apud RODRIGUES, 2014), a tradutora deve mapear as escolhas temáticas no texto-fonte para que possam utilizá-las de modo aceitável no texto-alvo, levando em consideraçăo particularidades culturais e linguísticas da língua-alvo.

A Linguística Sistêmico-Funcional é uma das teorias que embasa a Gramática do Design Visual, que repercute em estudos de traduçâo intermodal e de multimodalidade, como verificaremos a seguir.

De acordo com Kress (2003 apud DOLOUGHAN, 2011), a teoria e prática da traduçâo intermodal se dá na mudança de um signo para outro e no entendimento da "especializaçâo funcional de um modo em oposiçấo a outro em textos multimodais"6 (DOLOUGHAN, 2011, p. 26). Assim, é necessário entender quais informaçōes ou ideias sâo melhor realizadas visualmente; e quais sâo melhor realizadas verbalmente e o que pode acontecer na interaçấo do verbal e do visual para a produçáo e recepçâo de um texto (DOLOUGHAN, 2011). Para Doloughan (2011), o contexto social e cultural é importante para tal análise.

Kress (2003 apud DOLOUGHAN, 2011) acredita que as práticas literárias com as quais estamos acostumados estejam se modificando, caminhando em uma direçâo em que possam funcionar de forma multimodal.

Consoante Kress e van Leeuwen (2006 apud DOLOUGHAN, 2011), o visual apresenta sua própria gramática e sintaxe. Princípios do design e da composiçăo, por exemplo, sâo utilizados por escritoras para a construçâo de representaçóes e de significado (DOLOUGHAN, 2011). Dessa maneira, o que é excluído de uma composiçâo pode apresentar tanto significado como aquilo que é incluído (KRESS; van LEEUWEN, 2006 apud DOLOUGHAN, 2011).

Segundo Kress (2003 apud DOLOUGHAN, 2011), uma das diferenças entre os modos verbal e visual se dá no fato de que o visual nos apresenta algo determinado, enquanto a linguagem verbal é vista como sendo mais esquemática.

Doloughan (2011) analisa o uso do visual em Austerlitz (2002), de W. G. Sebald, utilizando-se de Sontag (1977 apud DOLOUGHAN, 2011), ao mostrar como as fotografias podem ser utilizadas em uma narrativa, e ao observar que a evidência presente em uma fotografia é paradoxal. As fotografias săo um registro do passado, mas também

\footnotetext{
$5 \quad$ No original: "demands language pragmatic selection along the whole translation process."

6 No original: "(...) the functional specialization of one mode as opposed to another in multimodal texts."
} 
săo arbitrárias (SONTAG, 1977 apud DOLOUGHAN, 2011). Utilizando-se da noçăo de Barthes (1977 apud DOLOUGHAN, 2011) de retórica da imagem, a autora conclui que o significado năo está presente nas fotografias, mas é relativizado no contexto em que elas aparecem e no modo como sâo apresentadas.

Os textos atuais sâo tipicamente multimodais, sendo a multimodalidade um fator inerente em vários aspectos da vida cotidiana (MATTHIESSEN, 2013 apud KARATZA, 2017). A multimodalidade seria, entăo, a convergência de mais de um modo de comunicaçăo em um mesmo texto, no qual todos os modos contribuem para a construçáo de significado (KARATZA, 2017).

Segundo Karatza (2017), os recursos semióticos trabalham em conjunto para a criaçăo do potencial de significado textual. Imagens mostram aquilo que levaria muito tempo para descrever, ao passo que a linguagem escrita representaria algo que é difícil de mostrar (KRESS, 2010 apud KARATZA, 2017). Além disso, a linguagem visual e a linguagem verbal possuem lógicas diferentes: o texto escrito é governado pela lógica do tempo e a imagem é governada pela lógica da espacialidade e simultaneidade (KRESS, 2003 apud KARATZA, 2017). O significado de um texto está presente em todos os modos simultaneamente, sendo que todos os modos contribuem, de uma maneira específica, para o significado geral do texto multimodal (KRESS et al, 2010 apud KARATZA, 2017).

Conforme Kress e van Leeuwen (2006), os modos semióticos linguísticos e visual têm suas formas particulares de realizaçăo. Por exemplo, o que é expresso na linguagem através de verbos de ação, é expresso no modo visual através de vetores (KRESS; van LEEUWEN, 2006). Entretanto, nem todas as relaçôes que podem ser feitas linguisticamente podem ser feitas visualmente e o oposto também é verdadeiro (KRESS; van LEEUWEN, 2006). As possibilidades de representaçâo nos diferentes modos semióticos săo determinadas pelas potencialidades e limitaçôes dos modos em si, além de serem, também, determinadas histórica e socialmente (KRESS; van LEEUWEN, 2006).

Kress e van Leeuwen (2006) consideram que pouco se estudou sobre a questăo da estruturaçáo visual, e que a estruturaçâo visual vem sendo tratada como mera reproduçâo da realidade. Para os autores, as imagens da realidade năo podem ser separadas dos interesses das instituiçôes sociais nas quais as imagens sâo produzidas e vistas. As estruturas visuais sâo ideológicas e possuem uma dimensăo semântica importante (KRESS; van LEEUWEN, 2006). Pensando nisso, os autores criam o que é conhecido como Gramática do Design Visual.

Uma imagem possui "Participantes" (KRESS; van LEEUWEN, 2006). Para os autores, existem dois tipos de Participantes em todos os atos semióticos: os Participantes Interativos e os Participantes Representados. Os primeiros seriam os Participantes que estáo envolvidos no ato de comunicaçáo, enquanto os segundos seriam aqueles que constituiriam o assunto da comunicaçâo.

Todas as escolhas de forma de um diagrama estăo carregadas de significado. Todas as formas geométricas apresentam significados que năo săo intrínsecos a elas, mas que advêm da cultura e sociedade em que estăo inseridas. A chave, entăo, para entender os textos visuais está no entendimento das possibilidades de uso da semiótica visual e de como reunir elementos heterogêneos em um todo coerente (KRESS; van LEEUWEN, 2006). 
Consoante os autores, os Participantes conectados por um vetor săo representados fazendo algo para o outro ou um para o outro. Tais padróes vetoriais sâo chamados de narrativa (KRESS; van LEEUWEN, 2006). Pode-se usar o termo presentacional em oposiçăo ao termo conceitual (KRESS; van LEEUWEN, 1990 apud KRESS; van LEEUWEN, 2006). Os padróes conceituais apresentam Participantes em termos de classe, estrutura e significado; já os padrôes narrativos apresentam açôes que estâo sendo desenvolvidas, além de eventos, processos de mudança e arranjos de transitoriedade espacial (KRESS; van LEEUWEN, 2006).

Como exemplo, podemos trazer Moya Guijarro (2014), que analisa como os autores de livros ilustrados infantis representam o mundo narrativo no modo verbal em relaçăo à transitividade/intransitividade; como os Processos, os Participantes e as Circunstâncias săo realizados nas ilustraçôes; e a intersemiose que é construída da relaçăo entre o verbal e o năo-verbal para a criaçăo do mundo narrativo; e, por último, como o fator de idade influencia no uso de estratégias verbais e visuais.

Consoante o autor, as representaçōes dos eventos nos livros ilustrados infantis analisados se dăo principalmente através dos Processos Material e Relacional, sendo que os Processos Materiais se referem a açóes realizadas pelos personagens principais. No livro Granpa, por exemplo, os Processos Materiais săo utilizados para representar atividade e movimento e o Processo Relacional representa 23.6\% das características identificadas (MOYA GUIJARRO, 2014). Em Dear Zoo, o Processo Relacional faz referência aos animais recebidos pela criança (MOYA GUIJARRO, 2014).

Os livros ilustrados infantis trazem textos narrativos e săo caracterizados por sua apresentaçăo concisa das personagens, a narraçăo simples do desenvolvimento da história e um breve relato do clímax (LLUCH, 2003; MOYA; ÁVILA, 2009 apud MOYA GUIJARRO, 2014).

Além dos Processos Material e Relacional, os Processos Mentais, os quais totalizam 11,8\% das características identificadas, săo utilizados para auxiliar na representaçăo do mundo narrativo (MOYA GUIJARRO, 2014). Os Processos Comportamental e Existencial, quando se trata da presença do verbal, săo menos importantes do que os outros Processos já apresentados, totalizando, respectivamente, 4,8\% e 1,1\% das características identificadas nos textos analisados (MOYA GUIJARRO, 2014). Nos textos para crianças no estágio sensório-motor năo há presença de Processos Mentais; estes sâo utilizados, no entanto, em histórias para crianças em outros estágios de desenvolvimento cognitivo (MOYA GUIJARRO, 2014). Os Processos Existenciais foram encontrados em histórias para crianças em todos os estágios de desenvolvimento cognitivo, mas sua presença é mínima (MOYA GUIJARRO, 2014), como já mencionado.

De forma correlacionada à linguagem verbal, os Processos visuais das ilustraçôes podem ser associados a Participantes específicos. 75,6\% das características analisadas săo de Processos visuais nos quais há uma relaçâo transacional de dois ou mais Participantes. Aspectos relacionados à transacionalidade ou à bidirecionalidade das imagens contribuem para a construçâo de relacionamentos pessoais. Em contrapartida, as relaçôes nâo transacionais indicam falta de contato ou isolamento (MOYA GUIJARRO, 2014).

De acordo com Moya Guijarro (2014), a relaçâo existente entre o verbal e o visual é de complementaridade. Ambos os modos semióticos se complementam para 
representar o mundo narrativo para a criança leitora, sendo a complementaçâo de texto e imagem muitas vezes essencial para o entendimento do enredo (MOYA GUIJARRO, 2014).

Pensando em traduçăo intermodal, intersemiótica e histórias em quadrinhos, podemos citar Frederico Zanettin (2008) o qual enfoca o uso de diversos e diferentes sistemas de signos. A traduçâo de quadrinhos de uma língua para a outra seria a traduçăo de uma cultura visual para outra, pois a traduçăo de quadrinhos deve levar em consideraçâo nâo apenas os sistemas linguísticos diferentes mas também os diferentes sistemas culturais e diferentes convençôes do que é e como se representa uma história em quadrinhos (ZANETTIN, 2008).

\section{METODOLOGIA}

\subsection{Maus e as traduçóes para o português}

Maus, produzido por Art Spiegelman, foi originalmente publicado entre 1989 e 1991 (e, de forma fragmentada, entre 1973 e 1991) e narra a história de Vladek Spiegelman, pai de Art, e suas experiências durante o período nazista da Segunda Guerra Mundial. A arte do quadrinho é inteiramente em preto e branco ${ }^{7}$.

O quadrinho é dividido em dois volumes e se alterna entre o presente e o passado. No presente, vemos Art produzindo a obra, entrevistando seu pai e enfrentando problemas tanto artísticos quanto pessoais. No passado, vemos a história de Vladek, desde meados dos anos 1930 até sua libertaçâo do campo concentraçăo de Auschwitz.

Maus, de acordo com Staub (1995), pode ser visto como uma forma de história oral - pois é a história de Vladek narrada para Art - que procura criar um envolvimento emocional entre a narrativa apresentada e a leitora, uma história que luta para representar uma memória de um momento irrepresentável. Dessa maneira, Maus também é uma forma de "contestaçăo" da história oficial que marginaliza, de muitas formas, as experiências de grupos oprimidos e perseguidos, enfocando, assim, a representaçăo das recordaçôes de um sobrevivente da Shoá (STAUB, 1995).

Para fins desta análise, além do texto-fonte, utilizamos as traduçóes de Maus para o português brasileiro e para o português europeu. A traduçăo para o português brasileiro foi feita por Antonio de Macedo Soares e publicada pela editora Companhia das Letras em 2009. A traduçấo para o português europeu foi feita por Joana Neves e publicada pela Bertrand Editora em 2017.

\subsection{Os quadrinhos selecionados}

Para Eisner (1985), os quadrinhos destacam-se por utilizar nâo somente a imagem ou a linguagem escrita, mas uma junçâo de ambas. Segundo o autor, é a uniâo entre a imagem e a linguagem escrita, usadas complementarmente e năo redundantemente,

7 Para saber mais sobre Maus, sua importância e seu projeto gráfico, acesse <https://historiazine.com/porque-todo-mundo-deveria-ler-maus-a-hq-de-art-spiegelman-4e9815f0133c〉. 
que formam uma história, a qual deve ser lida através de uma determinada sequência de imagens, o que, por sua vez, formará uma narrativa.

Cada quadro que forma uma história em quadrinhos apresenta alguns elementos: 0 quadro é formado pelo enquadro - aquilo que delimita o quadro -, as imagens, os balóes - que representam as falas ou os pensamentos - ou as legendas - as quais apresentam uma narraçăo ou mesmo falas em off (EISNER, 1985, 2005).

Os quadros selecionados encontram-se no início do primeiro volume de Maus, quando Art e seu pai, Vladek, se reúnem após o jantar para conversar. Um dos tópicos da conversa é o livro no qual Art está trabalhando, que seria um relato das experiências de Vladek durante a Segunda Guerra Mundial. Este livro, uma narrativa em quadrinhos, viria a se chamar Maus.

Sendo assim, os quadros em questâo foram escolhidos por serem os primeiros na graphic novel a apresentar um teor metafictício. A metaficçăo, ou metanarraçăo, é a ficçâo que trata da própria ficçăo, que apresenta em seu texto um comentário sobre a própria narrativa (HUTCHEON, 1984).

\subsection{Procedimentos de análise}

Para a realizaçăo da análise foram selecionadas categorias da linguagem verbal e da linguagem nâo-verbal, as quais sâo expostas a seguir.

Para as categorias verbais, foram levados em conta os Processos Material, Mental, Relacional, Verbal, Comportamental, Existencial e seus respectivos Participantes, expressos e elípticos, e as Circunstâncias (THOMPSON, 2014). De acordo com o autor, tais categorias estâo vinculadas à metafunçăo ideacional.

As categorias nâo-verbais foram empregadas do ponto de vista das Realizaçôes (KRESS; van LEEUWEN, 2006), como é mostrado a seguir.

- açăo transacional unidirecional ou bidirecional;

- açăo nâo-transacional;

- Participantes: Ator, Meta, Interator, Reagente, Fenômeno, Experienciador, Dizente, Enunciado;

- Reaçâo transacional ou nâo-transacional;

- Processos: Conversáo, Mental, Verbal, Meio, Fala, Reacionais, Analítico Embutido

- Circunstâncias: Locativas, Modo, Acompanhamento, Cenário [de acordo com Kress e van Leeuwen (2006), Acompanhamento e Cenário também podem ser considerados Participantes. Entretanto, para os fins de nossa análise, os consideramos apenas Circunstâncias].

De modo relacionado à Casali (2018), nossa análise foi organizada em quatro momentos. O primeiro tratou da análise do modo semiótico visual em comparaçáo com a linguagem verbal do texto-fonte e de suas traduçōes para o português. Após, analisamos comparativamente a linguagem verbal do texto-fonte e sua traduçáo para o português brasileiro e, a seguir, do texto-fonte e sua traduçâo para o português europeu. Por último, comparamos os textos traduzidos entre si. 


\section{RESULTADOS E DISCUSSÃO}

Esta seçăo apresenta os resultados encontrados na análise do excerto selecionado de Maus e de suas traduçôes para o português brasileiro e para o português europeu. Os resultados e a discussăo serăo feitos com base nos quatro quadros. O QUADRO 1 traz a linguagem visual e os QUADROS 2-4 trazem a linguagem verbal.

Em seguida, no QUADRO 1, apresentaremos os fenômenos visuais.

\section{QUADRO 1: A linguagem visual em um excerto de Maus: a survivor's tale/a história de um sobrevivente}

\begin{tabular}{|c|c|c|c|c|}
\hline & \multicolumn{4}{|c|}{ REALIZAÇÕES } \\
\hline & Participantes & Processos & Circunstâncias & $\begin{array}{c}\text { Ação/Reação } \\
\text { Transacional/Não- } \\
\text { Transacional }\end{array}$ \\
\hline Quadrinho 1 & $\begin{array}{l}\text { Dizente (Vladek); Enunciado; } \\
\text { Ator (Vladek); Meta (Art). }\end{array}$ & $\begin{array}{l}\text { Processo de Fala; } \\
\text { Processo de Ação. }\end{array}$ & Cenário & $\begin{array}{l}\text { Ação transacional } \\
\text { unidirecional }\end{array}$ \\
\hline Quadrinho 2 & $\begin{array}{l}\text { Dizentes (Vladek e Art); } \\
\text { Enunciados; Interatores } \\
\text { (Vladek e Art). }\end{array}$ & $\begin{array}{l}\text { Processos de Fala; } \\
\text { Processo de Ação. }\end{array}$ & Cenário & $\begin{array}{l}\text { Ação transacional } \\
\text { bidirecional }\end{array}$ \\
\hline Quadrinho 3 & Dizente (Art); Enunciado. & Processo de Fala. & Cenário & Ação não-transacional \\
\hline Quadrinho 4 & $\begin{array}{l}\text { Dizente (Art); Enunciado; } \\
\text { Interatores (Vladek e Art). }\end{array}$ & $\begin{array}{l}\text { Processo de Fala; } \\
\text { Processo de Ação. }\end{array}$ & Cenário & $\begin{array}{c}\text { Ação transacional } \\
\text { bidirecional }\end{array}$ \\
\hline Quadrinho 5 & $\begin{array}{c}\text { Dizente (Vladek); Enunciado; } \\
\text { Reagente (Vladek); } \\
\text { Fenômeno (Art). }\end{array}$ & $\begin{array}{l}\text { Processo de Fala; } \\
\text { Processo Reacional. }\end{array}$ & Cenário & $\begin{array}{l}\text { Reação transacional } \\
\text { unidirecional }\end{array}$ \\
\hline Quadrinho 6 & $\begin{array}{c}\text { Dizentes (Art e Vladek); } \\
\text { Enunciado; Interatores } \\
\text { (Art e Vladek). }\end{array}$ & $\begin{array}{l}\text { Processos de Fala; } \\
\text { Processo de Ação. }\end{array}$ & Cenário & $\begin{array}{l}\text { Ação transacional } \\
\text { bidirecional }\end{array}$ \\
\hline Quadrinho 7 & Dizente (Vladek); Enunciado. & Processo de Fala. & Cenário & Ação não-transacional \\
\hline Quadrinho 8 & Dizente (Vladek); Enunciado. & Processo de Fala. & Acompanhamento & Ação não-transacional \\
\hline
\end{tabular}

Fonte: SPIEGELMAN, 1991, 2009, 2017.

Na coluna dos Participantes, temos, primeiramente o Dizente, do qual o baláo de fala emana. Após, temos o Enunciado, que é o Participante verbal que está incluso no balâo de fala. O Ator é o Participante que está ativo em um Processo de açăo, sendo deste que o vetor emana; já a Meta é o Participante passivo em um Processo de Açăo em cuja direçăo o vetor se direciona. O Reagente é o Participante ativo em um Processo de Reaçăo, cujo olhar criará a linha de visăo. O Fenômeno é o Participante para o qual a linha de visăo do Reagente está direcionada. Por último, temos os Interatores, os quais săo Participantes em um Processo de Açâo Transacional. No caso dos Interatores, o vetor pode emanar, ou estar direcionado, a qualquer um dos dois (KRESS; van LEEUWEN, 2006).

Na coluna dos Processos, temos os Processos de Fala, de Açâo e o Processo Reacional. O Processo de Fala apresenta um baláo de fala e um Dizente. O Processo de Açăo apresenta a realizaçáo de algo e tem por Participante o Ator. O Processo Reacional é formado pelo campo de visăo dos Participantes (KRESS; van LEEUWEN, 2006).

Na coluna das Circunstâncias, temos o Cenário e o Acompanhamento. O Cenário acontece quando os Participantes se sobrepóe no primeiro plano e o segundo plano é 
desenhado com menos detalhe ou obscurecido pelos Participantes. A Circunstância de Acompanhamento se dá quando os Participantes, mesmo que ligados, năo apresentam vetores (KRESS; van LEEUWEN, 2006).

Por último, temos a coluna da Açăo/Reaçăo Transacional/Năo-Transacional. Uma Reaçăo Transacional apresenta uma linha de visăo que conecta dois Participantes. Assim, uma Reaçâo Transacional Unidirecional é uma Reaçăo Transacional que conecta um Ator e uma Meta. A Açáo Náo-Transacional possui um vetor que é formado pelo Ator, mas que nâo aponta para outro Participante. A Açáo Transacional Bidirecional forma um vetor que conecta dois Interatores. Já a Açăo Transacional Unidirecional conecta dois Participantes, um Ator e uma Meta (KRESS; van LEEUWEN, 2006).

A seguir, apresentaremos os QUADROS 2-4 com os fenômenos linguísticos.

QUADRO 2: A linguagem verbal em um excerto de Maus: a survivor's tale

\begin{tabular}{|c|c|c|c|}
\hline & Participantes & Processos & Circunstâncias \\
\hline Legenda 1 & Ator (Vladek); Meta (Art). & Processo Material & $\begin{array}{c}\text { Localização - } \\
\text { Temporal e Espacial }\end{array}$ \\
\hline Balãozinho 2 & $\begin{array}{l}\text { Ator (Art); Dizentes (Vladek e Art); } \\
\text { Ator (Vladek). }\end{array}$ & $\begin{array}{c}\text { Processos } \\
\text { Materiais; } \\
\text { Processo Verbal. }\end{array}$ & - \\
\hline Balãozinho 3 & $\begin{array}{l}\text { Portador; Atributo; Escopo; } \\
\text { Dizente (Art); Receptor (Vladek); Portador; } \\
\text { Escopo; Portador. }\end{array}$ & $\begin{array}{l}\text { Processos Relacionais } \\
\text { Atributivos; } \\
\text { Processo Verbal. }\end{array}$ & - \\
\hline Balãozinho 4 & Experienciador (Art); Fenômeno. & Processo Mental & Assunto \\
\hline Balãozinho 5 & $\begin{array}{l}\text { Verbiagem; Dizente Elíptico (Art); Receptor } \\
\text { (Vladek). }\end{array}$ & Processo Verbal & Assunto \\
\hline Balãozinho 6 & $\begin{array}{l}\text { Verbiagem Elíptica; Dizente Elíptico (Art); } \\
\text { Receptor Elíptico (Vladek). }\end{array}$ & Processo Verbal Elíptico & Assunto \\
\hline Balãozinho 7 & $\begin{array}{l}\text { Ator (Vladek); Meta; Experienciador; } \\
\text { Fenômeno. }\end{array}$ & $\begin{array}{l}\text { Processo Material; } \\
\text { Processo Mental }\end{array}$ & - \\
\hline Balãozinho 8 & $\begin{array}{c}\text { Experienciador (Art); Fenômeno; } \\
\text { Dizente (Vladek); Receptor (Anja); } \\
\text { Dizente (Vladek); } \\
\text { Receptor (Art); } \\
\text { Atores (Vladek e Anja). }\end{array}$ & $\begin{array}{l}\text { Processo Mental; } \\
\text { Processos Verbais; } \\
\text { Processo Material. }\end{array}$ & - \\
\hline Balãozinho 9 & Ator (Art); Meta; Ator; Meta; Benificiário (Art). & Processos Materiais & - \\
\hline Balãozinho 10 & $\begin{array}{l}\text { Experienciador (Art); Dizente Elíptico (Vladek); } \\
\text { Receptor (Art); Ator (Vladek). }\end{array}$ & $\begin{array}{l}\text { Processo Mental; } \\
\text { Processo Verbal; } \\
\text { Processo Material. }\end{array}$ & Localização - Espacial \\
\hline Legenda 11 & $\begin{array}{c}\text { Portador (Vladek); Ator (Vladek); Ator } \\
\text { (Vladek); Ator (Vladek); Ator (Vladek); Meta. }\end{array}$ & $\begin{array}{l}\text { Processo Relacional; } \\
\text { Processos Materiais. }\end{array}$ & Localização - Espacial \\
\hline
\end{tabular}

Fonte: SPIEGELMAN, 1991. 


\section{QUADRO 3: A linguagem verbal em um excerto de Maus: a história de um sobrevivente Tradução de Antônio de Macedo Soares}

\begin{tabular}{|c|c|c|c|}
\hline & Participantes & Processos & Circunstâncias \\
\hline Legenda 1 & Ator (Vladek e Art). & Processo Material & $\begin{array}{l}\text { Localização - } \\
\text { Temporal e Espacial }\end{array}$ \\
\hline Balãozinho 2 & Dizentes (Vladek e Art); Ator (Vladek). & $\begin{array}{l}\text { Processo Verbal; } \\
\text { Processo Material. }\end{array}$ & - \\
\hline Balãozinho 3 & $\begin{array}{c}\text { Atributo; Escopo; Portador; Dizente (Art); Receptor } \\
\text { (Vladek); Portador; Portador; Escopo. }\end{array}$ & $\begin{array}{l}\text { Processos Relacionais; } \\
\text { Processo Verbal. }\end{array}$ & - \\
\hline Balãozinho 4 & Experienciador (Art); Fenômeno. & Processo Mental & Assunto \\
\hline Balãozinho 5 & Verbiagem; Dizente Elíptico (Art); Receptor (Vladek). & Processo Verbal & - \\
\hline Balãozinho 6 & $\begin{array}{c}\text { Verbiagem Elíptica; Dizente Elíptico (Art); Receptor } \\
\text { Elíptico (Vladek). }\end{array}$ & Processo Verbal Elíptico & Assunto \\
\hline Balãozinho 7 & Ator (Vladek); Meta; Experienciador; Fenômeno. & $\begin{array}{l}\text { Processo Material; } \\
\text { Processo Mental. }\end{array}$ & - \\
\hline Balãozinho 8 & $\begin{array}{c}\text { Experienciador (Art); Dizente (Vladek); Receptor } \\
\text { (Anja); Dizente (Vladek); Experienciador (Vladek); } \\
\text { Fenômeno (Anja). }\end{array}$ & $\begin{array}{l}\text { Processos Mentais; } \\
\text { Processos Verbais. }\end{array}$ & - \\
\hline Balãozinho 9 & Ator Elíptico (Art); Meta; Ator; Meta; & Processos Materiais & - \\
\hline Balãozinho 10 & $\begin{array}{l}\text { Experienciador Elíptico (Art); Dizente Elíptico } \\
\text { (Vladek); Ator (Vladek). }\end{array}$ & $\begin{array}{l}\text { Processo Mental; } \\
\text { Processo Verbal; } \\
\text { Processo Material. }\end{array}$ & $\begin{array}{l}\text { Localização - } \\
\text { Espacial }\end{array}$ \\
\hline Legenda 11 & $\begin{array}{c}\text { Ator (Vladek); Ator Elíptico (Vladek); Ator Elíptico } \\
\text { (Vladek); Ator Elíptico (Vladek); }\end{array}$ & Processos Materiais & $\begin{array}{l}\text { Localização - } \\
\text { Espacial }\end{array}$ \\
\hline
\end{tabular}

Fonte: SPIEGELMAN, 2009.

\section{QUADRO 4: A linguagem verbal em um excerto de Maus: a história de um sobrevivente Tradução de Joana Neves}

\begin{tabular}{|c|c|c|c|}
\hline & Participantes & Processos & Circunstâncias \\
\hline Legenda 1 & Ator (Vladek); Meta (Art). & Processo Material & $\begin{array}{l}\text { Localização - } \\
\text { Temporal e Espacial }\end{array}$ \\
\hline Balãozinho 2 & Ator (Art); Dizentes (Vladek e Art); Ator (Vladek). & $\begin{array}{l}\text { Processos Materiais; } \\
\text { Processo Verbal. }\end{array}$ & - \\
\hline Balãozinho 3 & $\begin{array}{c}\text { Atributo; Escopo; Portador; } \\
\text { Dizente (Art); Portador Elíptico; Portador. }\end{array}$ & $\begin{array}{l}\text { Processos Relacionais; } \\
\text { Processo Verbal. }\end{array}$ & - \\
\hline Balãozinho 4 & Experienciador (Art); Fenômeno (Vladek). & Processo Mental & Assunto \\
\hline Balãozinho 5 & Verbiagem; Dizente (Art); Receptor (Vladek). & Processo Verbal & - \\
\hline Balãozinho 6 & $\begin{array}{c}\text { Verbiagem Elíptica; Dizente Elíptico (Art); Receptor } \\
\text { Elíptico (Vladek). }\end{array}$ & Processo Verbal Elíptico & Assunto \\
\hline Balãozinho 7 & Ator (Vladek); Meta; Experienciador; Fenômeno. & $\begin{array}{l}\text { Processo Material; } \\
\text { Processo Mental }\end{array}$ & - \\
\hline Balãozinho 8 & $\begin{array}{c}\text { Experienciador (Art); Dizente (Vladek); Receptor } \\
\text { (Anja); Dizente (Vladek); Receptor (Art); } \\
\text { Experienciadores Elípticos (Vladek e Anja). }\end{array}$ & $\begin{array}{l}\text { Processo Mentais; } \\
\text { Processos Verbais. }\end{array}$ & - \\
\hline Balãozinho 9 & Ator (Art); Meta; Ator; Meta; Benificiário (Art). & Processos Materiais & - \\
\hline Balãozinho 10 & $\begin{array}{l}\text { Experienciador Elíptico (Art); Dizente Elíptico } \\
\text { (Vladek); Ator Elíptico (Vladek). }\end{array}$ & $\begin{array}{l}\text { Processo Mental; } \\
\text { Processo Verbal; } \\
\text { Processo Material. }\end{array}$ & $\begin{array}{l}\text { Localização - } \\
\text { Espacial }\end{array}$ \\
\hline Legenda 11 & $\begin{array}{c}\text { Ator Elíptico (Vladek); Ator Elíptico (Vladek); } \\
\text { Característica Elíptica; Valor; Ator (Vladek); Meta. }\end{array}$ & $\begin{array}{l}\text { Processos Materiais; } \\
\text { Processo Relacional. }\end{array}$ & $\begin{array}{l}\text { Localização - } \\
\text { Espacial }\end{array}$ \\
\hline
\end{tabular}

Fonte: SPIEGELMAN, 2017. 
Na primeira coluna, apresentamos os Participantes. O Participante que comete a açăo é chamado de Ator. Já quando a açâo afeta o Participante, este Participante é chamado de Meta. O Dizente é o Participante que está envolvido em um Processo Verbal, sendo tipicamente humano, assim como o Receptor. Os Participantes Portador e Atributo estâo envolvidos em Processos Relacionais. Os Participantes Experienciador e Fenômeno ocorrem em Processos Mentais. A Verbiagem é a mensagem em si, presente em um Processo Verbal. O Beneficiário e o Escopo sâo outros Participantes que podem aparecer em um texto (THOMPSON, 2014). O Beneficiário teria uma correspondência ao "objeto indireto" e somente năo pode aparecer em Processos Existenciais. Já o Escopo aparece em Processos Materiais, identificando objetos que náo săo afetados pelo Processo (THOMPSON, 2014). Também levamos em conta os Participantes elípticos que sâo recuperados anaforicamente.

A segunda coluna refere-se aos Processos. Os Processos Materiais envolvem açōes físicas, enquanto os Processos Verbais colocam um enfoque nos verbos de fala, como "dizer", por exemplo. Os Processos Relacionais săo aqueles que apresentam uma relaçấo entre dois conceitos e sâo divididos em Relacional Atributivo e Relacional Identificativo. Os Processos Mentais representam algo que ocorre no mundo interno, na mente da usuária da língua (THOMPSON, 2014).

A terceira coluna apresenta as Circunstâncias, as quais sâo realizadas por Adjuntos Circunstanciais (THOMPSON, 2014). As Circunstâncias presentes na graphic novel, no original em inglês e em suas traduçóes para o português, săo Circunstâncias de Localizaçăo e de Assunto.

A seguir, analisaremos comparativamente o QUADRO 1 com os outros QUADROS para entendermos como se dá a traduçâo intermodal em Maus.

Primeiramente, compararemos o QUADRO 1 e o QUADRO 2. O QUADRO 1 apresenta 23 Participantes: Ator, realizado uma vez; Enunciado, realizado oito vezes; Dizente, realizado 8 vezes; Meta, realizado uma vez; Interatores, realizado três vezes; Reagente, realizado uma vez; e Fenômeno, realizado uma vez. Já o QUADRO 2, apresenta 16 Participantes. Assim, como o QUADRO 1, apresenta Atores, realizado dez vezes; Meta, realizado quatro vezes; e Dizente, realizado duas vezes.

Um exemplo da diferença entre os modos verbal e visual pode ser encontrado no primeiro quadrinho, o qual possui uma legenda e um baláo de fala. Podemos ver que, no QUADRO 1, no quadrinho 1, apresenta-se apenas um Dizente (Vladek, com Art na funçăo de Meta), enquanto no QUADRO 2, no balăo de fala 2, apresentam-se dois Dizentes. Isso se dá pois, na linguagem visual, o Dizente é aquele do qual o balăo de fala emana (KRESS; van LEEUWEN, 2006). Ademais, temos Vladek dizendo "Come - we'll talk while I pedal" (SPIEGELMAN, 1991, p. 12), colocando a açăo de fala em ambas as personagens.

Em relaçâo aos Processos de Fala, estes ocorrem sete vezes no QUADRO 1 e seis vezes no QUADRO 2, na forma de Processo Verbal e Processo Verbal Elíptico. As Circunstâncias realizam-se de modo distinto nos QUADROS 1 e 2 em funçấo do enfoque que é dado às linguagens verbal e visual.

Comparando o QUADRO 1 e o QUADRO 3, encontramos diferenças na realizaçâo do Ator (realizado 1 vez na linguagem visual e seis vezes na linguagem verbal). Podemos ver uma realizaçâo maior de Dizentes na linguagem visual do que na verbal. 
O QUADRO 3 apresenta várias instâncias de Participantes elípticos, Participantes que estăo referenciados, mas năo presentes no quadrinho, algo que é inviável para o QUADRO 1, pois os Participantes devem estar presentes visualmente para contarem como tais.

Em relaçâo ao QUADRO 1 e o QUADRO 4, podemos ver que o mesmo padrâo se repete. Participantes como Ator, o qual na linguagem visual estăo presentes uma vez por quadrinho, podem estar mais presentes na linguagem verbal.

Agora, analisaremos a traduçăo interlingual. Para tal, compararemos primeiramente o QUADRO 2 com o QUADRO 3 e, após, o QUADRO 2 com o QUADRO 4. Como mencionado na seçăo da metodologia, a traduçăo para o português brasileiro foi feita por Antonio de Macedo Soares e publicada pela editora Companhia das Letras em 2009, enquanto a traduçáo para o português europeu foi feita por Joana Neves e publicada pela Bertrand Editora em 2017.

Quando se trata de Participantes, os quadros apresentam diferenças em número e tipo de realizaçôes. O número de Atores é maior no QUADRO 2 do que no QUADRO 3. Isso pode se dar por causa da diferença gramatical entre as línguas, sendo que a língua inglesa tende a explicitar mais o sujeito da frase do que o português brasileiro.

Os dois quadros apresentam diferenças no número e tipos de Processos. Em relaçâo às Circunstâncias, as mesmas săo realizadas em ambos os quadros. Entretanto, a Circunstância Assunto é mais comum no QUADRO 2 do que no QUADRO 3.

Em relaçāo ao QUADRO 2 e o QUADRO 4, podemos notar uma diminuiçâo na ocorrência de Participantes Atores: no QUADRO 2 temos dez realizaçóes, enquanto que no QUADRO 4, temos seis realizaçóes. Os Participantes elípticos sâo mais recorrentes na traduçăo para o português europeu do que no original em inglês. No QUADRO 4 ocorrem 11 Participantes elípticos, enquanto que no QUADRO 2 ocorrem apenas quatro Participantes elípticos. No QUADRO 4, podemos ver três ocorrências de Atores Elípticos, uma no baláo de fala 10 e outra na legenda 11. Isso se dá por fatores linguísticos diferenciados das línguas. No original, temos a explicitaçăo do sujeito, como, por exemplo, em "I was in textile - buying and selling" (SPIEGELMAN, 1991, p. 12); enquanto isso, na traduçăo para português europeu, o sujeito da frase é elidido: "Trabalhava em têxteis, compra e venda" (SPIEGELMAN, 2017, p.14).

As Circunstâncias quase năo diferem na comparaçăo entre o QUADRO 2 e o QUADRO 4. Há apenas uma ocorrência de Assunto a menos na traduçáo para o português europeu. $\mathrm{O}$ mesmo ocorre em relaçăo aos Processos, que permanecem quase sem modificaçōes.

Agora, compararemos as duas traduçôes para o português, uma para o português brasileiro e outra para o português europeu (QUADROS 3 e 4, respectivamente).

Em relaçâo aos Participantes, ambas as traduçôes apresentam o mesmo número de ocorrência de Atores. O QUADRO 3 apresenta mais ocorrências de Participantes elididos do que o QUADRO 4. No entanto, o QUADRO 4 apresenta um maior número de ocorrência de Dizentes. Isso se dá no balăo de fala 8 . Na traduçăo para o português brasileiro, Art diz: "Eu quero. Comece pela mamáe... Como a conheceu?" (SPIEGELMAN, 2009, p. 14). Já a traduçăo para o português europeu utiliza o verbo "contar": "Eu quero ouvir. Começa pela mâe... Conta-me como se conheceram" (SPIEGELMAN, 2017, p. 14). 
As Circunstâncias sâo as mesmas, e em mesmo número, em ambas as traduçôes.

Os Processos realizam-se de forma semelhante nos dois quadros. No entanto, o QUADRO 3 apresenta sete ocorrências de Processos Materiais em relaçăo às seis do QUADRO 4; em contrapartida, o QUADRO 4 apresenta duas ocorrências de Processos Relacionais e o QUADRO 3, apenas uma.

Os dados das traduçóes para o português podem indicar como (MALMKJAER, 2003) esses excertos realizam os significados do ponto de vista da metafunçáo ideacional.

Com base nos resultados obtidos, podemos ver que a linguagem visual possui regras que sâo específicas a ela, sua própria gramática e sintaxe (KRESS; van LEEUWEN, 2006 apud DOLOUGHAN, 2011), assim como a linguagem verbal. A presença de um grande número de Processos de Açăo na linguagem visual auxilia para o entendimento e para a sensaçăo de continuidade da narrativa. De forma semelhante isso ocorre com a utilizaçâo dos Processos Materiais na linguagem escrita, os quais indicam movimento.

As açōes transacionais e nâo-transacionais, os Processos e os Participantes criam padrôes vetoriais (KRESS; van LEEUWEN, 2006) que também contribuem para a construçâo da narrativa. Através deles, podemos ver a interaçăo de Vladek e Art e vê-los se movimentando na história.

Podemos dizer que os elementos apresentados no modo semiótico visual dos quadrinhos analisados passam uma mensagem em si mesmos, tornando a leitura do visual tăo importante quanto a leitura da linguagem escrita, fazendo com que ambos sejam complementares e náo redundantes. O significado da graphic novel é construído a partir da junçâo e da interaçâo dos modos semióticos (KRESS et al, 2010 apud KARATZA, 2017).

Acreditamos que o conceito de traduçăo intermodal (DOLOUGHAN, 2011) se relaciona com o conceito de traduçâo intersemiótica (JAKOBSON, 1959/2007), porém pensamos que o primeiro ocorre em um mesmo veículo ao passo que o segundo se manifesta em veículos distintos. A título de exemplificaçăo, os quadrinhos e os balóes em Maus se encontram na mesma obra enquanto que um romance e sua traduçấo intersemiótica em um filme se realizam em meios diferentes, apesar da intrínseca relaçăo entre eles.

Os resultados obtidos văo ao encontro dos apresentados por Moya Guijarro (2014). Apesar de tratarmos de gêneros diferentes - Moya Guijarro (2014) analisa livros ilustrados infantis e nós, histórias em quadrinhos, mais precisamente, no caso de Maus, uma graphic novel năo voltada para o público infantil - ambos utilizam dos modos semióticos verbais e visuais para contar sua história.

Assim como em Moya Guijarro (2014), as representaçôes se dâo, em sua maior parte, através do Processo Material, utilizado para indicar açóes e acontecimentos. 0 autor traz que, no modo visual, os aspectos relacionados à transacionalidade ou à bidirecionalidade das imagens contribuem para a construçăo de relaçôes interpessoais. A falta de transacionalidade também pode ser vista em Maus, no qual as açôes nâotransacionais indicam a falta de interaçăo entre as personagens. No quadrinho 3, por exemplo, temos um exemplo de açâo năo-transacional, pois nenhum dos vetores que emanam do olhar dos Participantes está apontando para outro Participante - Vladek está olhando para frente e Art está olhando uma foto em um retrato. 


\section{CONSIDERAÇÕES FINAIS}

Na Introduçăo, elencamos as perguntas que norteariam a nossa pesquisa, as quais eram: como se realiza o modo semiótico visual nos excertos selecionados? De que maneira ele dialoga com o modo verbal? Como se realiza a traduçăo interlingual? E, por fim, o que pode ser dito ao compararmos as traduçôes do ponto de vista verbal?

Neste momento, após a análise, da apresentaçâo dos resultados e da discussâo sobre estes, tentaremos responder as perguntas de pesquisa que havíamos proposto.

Após a análise de um trecho da graphic novel Maus (1991) e das traduçôes para o português do mesmo trecho, podemos dizer que o modo semiótico visual se dá a partir de sua própria gramática ou sintaxe (como visto em KRESS; van LEEUWEN, 2006 apud DOLOUGHAN, 2011), ou seja, de Processos, Participantes e Circunstâncias específicos que, juntos, nos levam ao entendimento do que está acontecendo na cena e que nos permitem entender a relaçâo e a interaçâo entre as personagens.

Quando se trata do diálogo do modo semiótico visual com o modo verbal, podemos observar o que foi dito por Kress e can Leeuwen (2006) de que os modos semiótico visual e verbal náo săo maneiras diferentes de expressar a mesma coisa, sendo que os dois modos sâo complementares e năo redundantes. De acordo com Doloughan (2011), a traduçâo intermodal se dá na relaçâo entre os dois modos semióticos. Segundo Kress (2003 apud DOLOUGHAN, 2011), a teoria e prática da traduçăo intermodal ocorre na mudança de um signo para outro e no entendimento da "especializaçáo funcional de um modo em oposiçăo a outro em textos multimodais"8 (DOLOUGHAN, 2011, p. 26). Assim, consoante Kress (2003 apud DOLOUGHAN, 2011), é necessário entender quais informaçóes ou ideias săo melhor realizadas visualmente; e quais sâo melhor realizadas verbalmente e o que pode acontecer na interaçáo do verbal e do visual para a produçăo e recepçấo de um texto. Cabe relembrar que as Realizaçôes no modo semiótico visual săo mais materiais do que no modo semiótico verbal, pois, segundo Kress (2003 apud DOLOUGHAN, 2011), a linguagem visual nos apresenta elementos concretos e determinados.

Segundo Rodrigues (2014), a traduçâo interlingual é uma atividade que demanda escolhas, isto é, "demanda a seleçăo pragmática da língua durante o processo de traduçấo"9 (RODRIGUES, 2014, p. 188). Assim, quando se trata da traduçấo interlingual, podemos ver diferenças em número e ocorrência de Participantes, Processos e Circunstâncias. Tais diferenças podem ser explicadas pelos fatores linguísticos diferenciados das línguas envolvidas.

Podemos ver, nos resultados, que os Participantes, as Circunstâncias e os Processos assemelham-se nas duas traduçôes. A traduçâo para o português europeu apresenta um maior número de Dizentes, enquanto a traduçăo para o português brasileiro apresenta um maior número de Participantes elididos. Isso pode ser atribuído ao caráter formal e específico da utilizaçâo de cada variedade da língua portuguesa.

8 No original: “(...) the functional specialization of one mode as opposed to another in multimodal texts."

9 No original: "demands language pragmatic selection along the whole translation process." 


\section{REFERÊNCIAS}

CASALI, Luisa Kiesling. A traduçăo intermodal e interlinguística: uma perspectiva semântico-discursiva sobre a narrativa ilustrada infantil Clifford the Big Red Dog e sua reinstanciaçăo em português. 2018. 36 f. TCC (Graduaçăo) - Curso de Letras Inglês Com ênfase em Estudos da Traduçăo, Letras, Universidade Federal de Minas Gerais, Belo Horizonte, 2018.

DOLOUGHAN, Fiona J. Contemporary narrative: textual production, multimodality and multiliteracies. London and New York: Continuum, 2011.

EISNER, Will. Comics and sequential art. Florida: Poorhouse Press, 1985.

EISNER, Will. Narrativas gráficas. Traduçăo Leandro Luigi Del Manto. Săo Paulo: Devir, 2005.

HALLIDAY, Michael Alexander Kirkwood; MATTHIESSEN, Christian Matthias Ingemar Martin. Halliday's Introduction to Functional Grammar. London and New York: Routledge, 2014.

HUTCHEON, Linda. Narcissistic narrative: the metafictional paradox. New York: Methuen, 1984.

JAKOBSON, Roman. Aspectos linguísticos da traduçâo. Traduçăo de Izidoro Blikstein e José Paulo Paes. In: __. Linguística e comunicaçăo. Săo Paulo: Editora Cultrix, 2007. p. 63-72.

KARATZA, Styliani. Analysing multimodal texts and test tasks for reading comprehension in the KPG exams in English. 2017. $562 \mathrm{f}$. Tese (Doutorado) - Curso de English Language And Literature, Philosophy, National And Kapodistrian University Of Athens, Athens, 2017.

KRESS, Gunther; van LEEUWEN, Theo. Reading images: the grammar of visual design. London and New York: Routledge, 2006.

MALMKJAER, Kirsten. Translational stylistics: Dulcken's translations of Hans Christian Andersen. Language and Literature. London: SAGE publications. v. 13 (1), 2004. p. 13-24.

MALMKJAER, Kirsten. What happened to God and the angels: an exercise in translational stylistics. Target, Amsterdam, v. 15, 2003. p. 37-58.

MOYA GUIJARRO, Arsenio Jesús. A multimodal analysis of picture books for children: a systemic functional approach. Bristol: Equinox Publishing, 2014.

RODRIGUES, Roberta Rego. Participants 'você' and 'you' in translation. Cadernos de Traduçăo, [s.l.], v. 2, n. 34, p.186-205, 4 dez. 2014. Universidade Federal de Santa Catarina (UFSC).

SPIEGELMAN, Art. Maus: a survivor's tale. New York: Pantheon Books, 1991.

SPIEGELMAN, Art. Maus: a história de um sobrevivente. Traduçâo de Joana Neves. Lisboa: Bertrand Editora, 2017.

SPIEGELMAN, Art. Maus: a história de um sobrevivente. Traduçâo Antonio de Macedo Soares. Săo Paulo: Companhia das Letras, 2009. 
STAUB, Michael. The Shoah goes on and on: remembrance and representation in Art Spiegelman's Maus. MELUS, v. 20, n. 3, p. 33-46, 1995.

THOMPSON, Geoff. Introducing Functional Grammar. London and New York: Routledge, 2014.

ZANETTIN, Federico (org.). Comics in translation. London and New York: Routledge, 2008. 